\title{
Carbon Dioxide Fixation by Verticillium albo-atrum
}

\author{
By R. E. HARTMAN, N. T. KEEN AND M. LONG \\ Department of Biology, St Bonaventure University, St Bonaventure, New York, \\ I 4778 and Department of Plant Pathology, University of California, \\ Riverside, California, 92502, U.S.A.
}

(Received I3 March I972; revised I5 May 1972)

SUMMARY

\begin{abstract}
Verticillium albo-atrum required $\mathrm{CO}_{2}$ for growth when glucose or glycerol was the sole carbon source but not when succinate or acetate was supplied. The yeast form of the fungus fixed ${ }^{14} \mathrm{C}$ from $\mathrm{NaH}^{14} \mathrm{CO}_{3}$ into extracellular metabolites (I to $2 \%$ ), low-molecular-weight intracellular components ( $17 \%)$, lipids $(3 \%)$, nucleic acids $(34 \%)$ and proteins $(42 \%)$. The only radioactive protein components were aspartate $(33 \%)$, glutamate $(33 \%)$, arginine +lysine $(22 \%)$, and leucine + isoleucine $(6 \%)$. Nucleic acid bases that contained appreciable ${ }^{14} \mathrm{C}$ were uracil $(27 \%)$, cytosine $(2 \mathrm{r} \%)$, adenine $(22 \%)$, guanine $(27 \%)$ and thymine $(4 \%)$. Carbon dioxide fixation appeared to be important for the anaplerotic biosynthesis of fourcarbon intermediates and for purine biosynthesis.
\end{abstract}

\section{INTRODUCTION}

Carbon dioxide stimulates growth and influences morphology in many fungi. Increased growth due to $\mathrm{CO}_{2}$ occurs in Curvularia, Cochliobolus and Chaetomium (Macauley \& Griffin, I969), Blastocladiella (Cantino \& Horenstein, I956), Fusarium (Stover \& Frieberg, 1958) and Rhizopus (Barinova, 1954) and enhanced germination of conidiospores in Aspergillus niger (Vakil, Rao \& Bhattacharya, 196I). Formation of thick-walled resistant sporangial cells of Blastocladiella emersonii was induced by the addition of bicarbonate to the growth medium (Cantino, 1956). Addition of $\mathrm{CO}_{2}$ to air promoted the growth of two species of Trichophyton as macrospores rather than as the normal mycelial forms (Chin \& Knight, I957). Carbon dioxide initiated swellings similar to appressoria on uredospore germ tubes of Puccinia striiformis (Macko \& Fuchs, 1970) and induced production of the yeast phase in some dimorphic fungi such as Mucor rouxii (Bartnick-García, 1963), Sporotrichum schencki (Drouhet \& Mariat, I952), Histoplasma farciminosum (Bullen, I949) and Cladosporium wernickii (Houston, Myer, Thomas \& Wolf, 1969).

Verticillium albo-atrum causes a vascular wilt disease of cotton and is dimorphic (Keen, Wang, Long \& Erwin, I97I). In stationary liquid culture the fungus produces mycelial growth while in shaken culture it grows predominantly as primary and secondary spores (Buckley, Wyllie \& DeVay, I969). Although the latter investigators referred to the spores as conidia, here they will be called the yeast form as proposed by Wang \& Bartnicki-García ( 1970 ). The significance of the yeast form for pathogenicity is indicated by observations that infection of the upper parts of plants results from the upward movement of the spores (or yeast form) in the xylem vessels (Presley, Carns, Taylor \& Schnathorst, I966). We have examined the effects of $\mathrm{CO}_{2}$ on the growth of the yeast form of $V$. albo-atrum and the utilization of $\mathrm{NaH}^{14} \mathrm{CO}_{3}$ in biosynthesis. 


\section{METHODS}

Organism and cultivation. One stock slope culture (inoculated with a single spore) of Verticillium albo-atrum (strain v3H, which causes defoliation of cotton plants; Erwin, Moje \& Malca, I965) was used. Except as noted in Table $\mathrm{I}$, the yeast form was grown in a glucose (25 g/l)-ammonium nitrate medium, pH 6.3, of Malca, Erwin, Moje \& Jones ( 1966$)$, which was modified by the addition of biotin ( $10 \mu \mathrm{g} / \mathrm{l}$ ) and sterilized by autoclaving ( $2 \mathrm{I}{ }^{\circ} \mathrm{C}$, I 5 min) the phosphate solution separately from the other components before combining aseptically. Eighty $\mathrm{ml}$ of culture was incubated in a $250 \mathrm{ml}$ Erlenmyer flasks shaken at 80 to 90 reciprocal strokes per min at $25^{\circ} \mathrm{C}$.

Yeast-cell suspensions of Verticillium albo-atrum were prepared by filtering cultures through nylon net (I 200 mesh per $\mathrm{cm}^{2}$ ) to remove any mycelial growth, and washing and resuspending the cells in sterile distilled water. Cells were sedimented by centrifuging for $5 \mathrm{~min}$ at $5000 \mathrm{~g}$.

Determination of ${ }^{14} \mathrm{CO}_{2}$ fixation. Aqueous $\mathrm{NaH}^{14} \mathrm{CO}_{3}$ was obtained from International Chemical and Nuclear Corporation, Irvine, California $(50 \mathrm{mCi} / \mathrm{mm})$. It was diluted in $0.001 \mathrm{~N}-\mathrm{NaOH}$ to prepare stock solutions.

To determine cellular ${ }^{14} \mathrm{C}$ incorporation, yeast cells were incubated in $\mathrm{NaH}^{14} \mathrm{CO}_{3}$, the suspension was centrifuged and the cells were washed twice and resuspended in $2.0 \mathrm{ml}$ distilled water. The second wash contained no radioactivity, so it was concluded that contaminating extracellular ${ }^{14} \mathrm{C}$ had been removed. Duplicate $0.5 \mathrm{ml}$ samples of the suspension were assayed for radioactivity.

To determine ${ }^{14} \mathrm{C}$ fixation in the supernatant, $\mathrm{I} \cdot 8 \mathrm{ml}$ of supernatant fluids from the sedimented cells was acidified by the addition of $0.2 \mathrm{ml}$ of $2 \mathrm{~N}-\mathrm{HCl}$ and flushed with $\mathrm{CO}_{2}$ for I $5 \mathrm{~min}$. Duplicate $0.5 \mathrm{ml}$ samples were assayed for radioactivity.

Cells were fractionated by the method of Roberts et al. (I955). Protein was hydrolysed in a sealed glass tube in $6 \mathrm{~N}-\mathrm{HCl}$ at $12 \mathrm{r}{ }^{\circ} \mathrm{C}$ for $6 \mathrm{~h}$ (Wang \& Willis, 1965). A sample of the hydrolysed protein that had been neutralized by repeated evaporation in vacuo was used to assay the radioactivity in the protein fraction. The nucleic acid fraction was hydrolysed in a stoppered tube with I I $\mathrm{N}$-perchloric acid at $100{ }^{\circ} \mathrm{C}$ for I $\mathrm{h}$. After cooling, the hydrolysate was diluted with water, centrifuged and the resulting clear solution was used for paper chromatography.

Radioactivity was determined by adding samples to Io $\mathrm{ml}$ of Bray's solution (Bray, I960) and measuring the radioactivity in a liquid scintillation counter (Packard Tri-Carb). Generally total counts in excess of 10000 were collected; however, when this number was not obtained in Io min, the Io min count was used. Background corrections were made. Since the extent of quenching did not differ significantly among the samples (about $5 \%$ ), corrections were not applied.

\section{RESULTS}

Effect of $\mathrm{CO}_{2}$ on growth. $\mathrm{A} \mathrm{CO}_{2}$-free atmosphere severely inhibited the growth of Verticillium albo-atrum in shaken cultures on glucose and glycerol, but had negligible effect upon growth on succinate or acetate (Table I). Inhibition of growth on glucose and glycerol was also observed when commercial mixtures containing $80 \%$ nitrogen and $20 \%$ oxygen were bubbled through the cultures; these mixtures presumably lacked $\mathrm{CO}_{2}$. Growth on glucose or glycerol in the $\mathrm{CO}_{2}$-free cultures could be restored to the control values by bubbling pure $\mathrm{CO}_{2}$ into the final water traps at $\mathrm{I}$ to $\mathrm{I} 0 \mathrm{ml} / \mathrm{min}$. Growth of the fungus was predominantly as the yeast form in all experiments. Bubbling air containing $10 \% \mathrm{CO}_{2}$ through Verticillum 
Table I. The effect of excluding $\mathrm{CO}_{2}$ on the growth of Verticillium albo-atrum*

\begin{tabular}{|c|c|c|c|}
\hline \multirow[b]{2}{*}{ Carbon source } & \multicolumn{2}{|c|}{ Growth $\dagger$} & \multirow{2}{*}{$\begin{array}{c}\text { Reduction } \\
\text { in growth } \\
(\%) \text { in } \\
\text { absence } \\
\text { of } \mathrm{CO}_{2}\end{array}$} \\
\hline & $\operatorname{Air}_{4}^{+}$ & $\begin{array}{c}\text { Air } \\
\text { minus } \mathrm{CO}_{2} \ddagger\end{array}$ & \\
\hline Glucose & $4 \cdot 8$ & 0.28 & 94 \\
\hline Glycerol & $5 \cdot 2$ & 0.14 & 97 \\
\hline Succinate & 1.6 & $\mathrm{r} \cdot 6$ & 0 \\
\hline Acetate & $2 \cdot I$ & $2 \cdot 2$ & 0 \\
\hline
\end{tabular}

* Inoculum was $10^{7}$ cells $/ \mathrm{ml}$; carbon sources were I \% $(\mathrm{w} / \mathrm{v})$; flasks were shaken at $25{ }^{\circ} \mathrm{C}$ for 43 h except for the acetate set which was incubated for $67 \mathrm{~h}$ to achieve maximum growth.

$\dagger$ Numbers represent cells $\times 10^{8} / \mathrm{ml}$ as determined by haemocytometer.

* Aeration was at about $100 \mathrm{ml} / \mathrm{min}$. Carbon dioxide removal was by passage through $\mathrm{NaOH}$, Ascarite (A. H. Thomas Co., Philadelphia, Pennsylvania, U.S.A.), and water traps; control flasks were supplied by air passed through water.

Table 2. Distribution of ${ }^{14} \mathrm{C}$ in cellular fractions of Verticillium albo-atrum cells exposed to $\mathrm{NaH}^{4} \mathrm{CO}_{3}$

\begin{tabular}{lcc}
\multicolumn{1}{c}{ Preparation* } & \multicolumn{2}{c}{ Total radioactivity } \\
Total ${ }^{14}$ C fixed & 2435900 & $\%$ \\
Washed cells & 2402300 & 100 \\
Supernatant fluid & 33600 & $98 \cdot 6$ \\
Cellular fractions & 2153500 & $1 \cdot 4$ \\
Low molecular weight (cold-TCA-soluble) & 374000 & 100 \\
Lipids (EtOH-soluble, EtOH-ether-soluble) & 64600 & $17 \cdot 4$ \\
Nucleic acids (hot-TCA-soluble) & 738900 & $3 \cdot 0$ \\
Acid-EtOH, ether washes & 28700 & $34 \cdot 3$ \\
Protein (residual protein and cell walls) & 913400 & $42 \cdot 4$
\end{tabular}

* A cell suspension $(25 \mathrm{ml})$ containing $10^{8}$ cells $/ \mathrm{ml}$ and $\mathrm{NaH}^{14} \mathrm{CO}_{3}(5 \mu \mathrm{Ci} / \mathrm{ml})$ was incubated for $3 \mathrm{~h}$; $\mathrm{TCA}=$ trichloroacetic acid; $\mathrm{EtOH}=$ ethyl alcohol; total ${ }^{14} \mathrm{C}$ fixed was $3.8 \%$ of that supplied.

cultures or supplementing cultures with $\mathrm{KHCO}_{3}$ did not give growth greater than in controls aerated with atmospheric air.

Carbon dioxide fixation. Suspensions of yeast form Verticillium albo-atrum exposed to $\mathrm{NaH}^{14} \mathrm{CO}_{3}$ for $3 \mathrm{~h}$ at $25{ }^{\circ} \mathrm{C}$ retained over $98 \%$ of the ${ }^{14} \mathrm{CO}_{2}$ fixed inside the cells (Table 2). Of the ${ }^{14} \mathrm{CO}_{2}$ fixed, low-molecular-weight components contained $17.4 \%$, lipids $3.0 \%$, nucleic acids $34 \%$, and the protein fraction $42 \%$. Protein hydrolysates showed the greatest radioactivity in aspartate and glutamate $(33 \%$ each), while the arginine + lysine fraction had $22 \%$, the leucine + isoleucine fraction $6 \%$ and glycine $3 \%$. No other amino acids contained significant radioactivity. Nucleic acid hydrolysates showed that the radioactivity was distributed in adenine $(22 \%)$, guanine $(27 \%)$, uracil $(27 \%)$, cytosine $(21 \%)$ and thymine $(4 \%)$ (Table 3).

\section{DISCUSSION}

The $\mathrm{CO}_{2}$ requirement for growth on glucose and glycerol but not succinate or acetate suggests an anaplerotic role for $\mathrm{CO}_{2}$ in the biosynthesis of four-carbon compounds when the fungus is grown on $\mathrm{C}_{3}$ compounds or hexoses. The lack of a $\mathrm{CO}_{2}$ requirement on acetate is consistent with enzymatic evidence for the glyoxylate cycle in the fungus (Tokunaga et al. 
Table 3. Radioactivity of protein and nucleic acid extracts

$\begin{array}{lrr}\quad \text { Component } & \text { Radioactivity } \\ \text { Protein hydrolysate* } & & \% \\ \text { Glutamate } & \text { I } 500 & 33 \\ \text { Aspartate } & \text { I } 500 & 33 \\ \text { Arginine+lysine } & \text { I000 } & 22 \\ \text { Leucine+ isoleucine } & 300 & 6 \\ \text { Glycine } & \text { I50 } & 3 \\ \text { Nucleic acid hydrolysatet } & & \\ \text { Guanine } & & 27 \\ \text { Adenine } & 570 & 22 \\ \text { Uracil } & 460 & 27 \\ \text { Cytcine } & 580 & 2 \text { I } \\ \text { Thymine } & 450 & 4\end{array}$

* Amino acids were separated by descending paper chromatography with butanol:acetic acid:water $(4: \mathrm{I}: 5)$ in one direction and thigh-voltage electrophoresis in $0.02 \mathrm{M}$-sodium borate, $\mathrm{pH} 9.2$, in the second direction by means of techniques devised by Drs T. G. James and E. Noltmann, Department of Biochemistry, University of California, Riverside (manuscript in preparation). Unlabelled amino acid standards were run with the hydrolysates. Ninhydrin-reacting areas were cut from the chromatograms and the paper added to scintillation vials for counting. Amino acids with less than $2 \%$ of the radioactivity were not included in the table.

$\dagger$ Nitrogen bases were separated by descending paper chromatography with either $95 \%$ EtOH:ammonium acetate $(7: 3)$ or isopropanol: $12 \mathrm{~N}-\mathrm{HCl}$ : water $(\mathrm{I} 70: 4 \mathrm{I}: 39)$. Standards were run with the hydrolysate, u.v. light-absorbing $(254 \mathrm{~nm})$ areas were cut from the chromatogram and added to scintillation vials for counting.

1969). Succinate reduces the $\mathrm{CO}_{2}$ requirement for growth of the Phycomycete, Aqualinderella fermentans (Emerson \& Held, I969).

The low level of growth in the absence of $\mathrm{CO}_{2}$ with glucose or glycerol as carbon sources presumably results from a deficiency of the glyoxylate pathway enzymes. This deficiency would result in a shortage of four-carbon intermediates in the absence of $\mathrm{CO}_{2}$. Repression of glyoxylate enzymes during growth on glucose has been demonstrated in several organisms. When Escherichia coli was grown in a medium containing a limiting amount of glucose, the glyoxylate cycle was repressed but when the glucose became exhausted, isocitrate lyase was derepressed and the bacteria grew at the expense of the acetate which had accumulated in the medium during growth on glucose (Holms \& Bennett, I97I). Rhizopus nigricans exhibited enhanced synthesis of malate synthase (Wegener, Schell \& Romano, 1967) and isocitratase (Wegener \& Romano, I964) when grown on acetate and decreased synthesis of these enzymes when grown on glucose.

The preferential uptake of ${ }^{14} \mathrm{C}$ from carbonate into those amino acids directly synthesized from TCA cycle intermediates (aspartate, glutamate, arginine, and isoleucine; Table 3) also supports the anaplerotic function of $\mathrm{CO}_{2}$ fixation in the synthesis of fourcarbon compounds by Verticillium albo-atrum. Similar incorporations of ${ }^{14} \mathrm{CO}_{2}$ into amino acids by several fungi have been reported. Penicillium chrysogenum incorporated high levels of ${ }^{14} \mathrm{CO}_{2}$ into aspartate, glutamate, and arginine (Gitterman \& Knight, 1952), Neocosmospora vasinfecta fixed carbon into aspartate and glutamate and a lesser quantity into tyrosine (Budd, 1969), and uredospores of Uromyces phaseoli used $\mathrm{CO}_{2}$ in the synthesis of aspartate, glutamate, and alanine (Staples \& Weinstein, 1959).

The radioactivity associated with uracil, cytosine, and thymine (Table 3 ) can also be attributed to anaplerotic $\mathrm{CO}_{2}$ fixation since it has been generally established that aspartate 
is a precursor of pyrimidines (Mahler \& Cordes, I97I). The radioactivity of adenine and guanine, on the other hand, probably resulted from the direct carboxylation that occurs in the synthesis of purines (Mahler \& Cordes, 197I). Neocosmospora vasinfecta incorporated labelled $\mathrm{CO}_{2}$ into guanine, adenine, uridylate, cytidylate and thymidylate (Budd, I969). Germinating conidiospores of Aspergillus niger fixed high levels of ${ }^{14} \mathrm{C}$ into uridine, cytosine, and adenine with lower levels into guanine and thymine (Yanagita, I963), and uredospores of Uromyces phaseoli incorporated more ${ }^{14} \mathrm{C}$ into purine than into pyrimidines (Stallknecht \& Mirocha, I97I).

Research supported by grant no. 7I6-I5-4 from the United States Department of Agricuiture Cooperative State Research Service.

\section{REFERENCES}

Barinova, S. A. (1954). Mikrobiologiya 23, 521-526. Cited by Cantino, E. C. and Turian, G. F. (1959). Physiology and development of lower fungi (Phycomycetes). Annual Review of Microbiology 13, 97-124.

Bartnicki-García, S. (1963). Symposium on biochemical bases of morphogenesis in fungi. III. Mold-yeast dimorphism of Mucor. Bacteriological Reviews 27, 293-304.

BraY, G. A. (1960). A simple efficient liquid scintillator for counting aqueous solutions in a liquid scintillation counter. Analytical Biochemistry I, 279-285.

Buckley, P. M., Wyllie, T. D. \& DeVAy, J. E. (1969). Fine structure of conidia and conidium formation in Verticillium albo-atrum and $V$. nigrescens. Mycologia 6r, 240-250.

BudD, K. (1969). The assimilation of bicarbonate by Neocosmospora vasinfecta. Canadian Journal of Microbiology 15, 389-398.

Bullen, J. J. (1949). The yeast-like form of Cryptococcus farciminosus (Histoplasma farciminosum). Journal of Pathology and Bacteriology 6r, I $17-120$.

Cantino, E. C. (1956). The relation between cellular metabolism and morphogenesis in Blastocladiella. Mycologia 48, 225-240.

Cantino, E C. \& Horenstein, E. A. (1956). The stimulatory effect of light upon growth and $\mathrm{CO}_{2}$ fixation in Blastocladiella. I. The S.K.I. cycle. Mycologia 48, 777-799.

ChIN, B. \& KNIGHT, S. G. (1957). Growth of Trichophyton mentagrophytes and Trichophyton rubrum in increased carbon dioxide tensions. Journal of General Microbiology 16, 642-646.

Drouhet, E. \& Mariat, F. (1952). Étude des facteurs déterminant le développement de la phase levure de Sporotrichum schencki. Annales de'Institut Pasteur 83, 506-514.

Emerson, R. \& Held, A. A. (1969). Aqualinderella fermentans gen. et sp. n., a phycomycete adapted to stagnant waters. Il. Isolation, cultural characteristics, and gas relations. American Journal of Botany 56, I IO3-I I 20.

Erwin, D. C., Moje, W. \& Malca, I. (1965). An assay of the severity of Verticillium wilt of cotton plants inoculated by stem puncture. Phytopathology 55, 663-665.

Gitterman, C. O. \& Knight, S. G. (I952). Carbon dioxide fixation into amino acids of Penicillium chrysogenum. Journal of Bacteriology 64, 223-231.

Holms, W. H. \& BenNeTT, P. M. (197I). Regulation of isocitrate dehydrogenase in Escherichia coli on adaptation to acetate. Journal of General Microbiology 65, 57-68.

Houston, M. R., Myer, K. H., Thomas, N. \& Wolf, F. T. (1969). Dimorphism in Cladosporium werneckii. Sabouraudia 7, 195-198.

Keen, N. T., WANG, M. C., Long, M. \& ERwin, D. C. (197I). Dimorphism in Verticillium albo-atrum as affected by initial spore concentration and antisporulant chemicals. Phytopathology 6r, 1 266-1269.

Macauley, B. J. \& Griffin, D. M. (1969). Effect of carbon dioxide and the bicarbonate ion on the growth of some soil fungi. Transactions of the British Mycological Society 53, 223-228.

Macko, V. \& FUCHS, E. (I970). Effect of carbon dioxide on uredospore germ tubes of Puccinia striiformis. Phytopathology 60, 1529-1530.

MAhler, H. R. \& CoRdes, E. H. (1971). Biological Chemistry, 2nd edn., pp. 820-834. New York: Harper \& Row.

Malca, I., Erwin, D. C., MoJe, W. \& Jones, B. (1966). Effects of pH and carbon and nitrogen sources on the growth of Verticillium albo-atrum. Phytopathology 65, 401-406. 
Presley, J. T., Carns, H. R., Taylor, E. E. \& Schnathorst, W. C. (I966). Movement of conidia of Verticillium albo-atrum in cotton plants. Phytopathology 56, 375.

Roberts, R. B., Abelson, P. H., Cowie, D. B., Bolton, E. T. \& Britten, R. J. (1955). Studies of Biosynthesis in Escherichia coli, pp. 13-I4. Publication 607. Washington, D.C.: Carnegie Institution.

StallKNecht, G. F. \& Mirocha, C. J. (I97I). Fixation and incorporation of $\mathrm{CO}_{2}$ into ribonucleic acid by germinating uredospores of Uromyces phaseoli. Phytopathology 6r, 400-405.

Staples, R. C. \& Weinstein, L. H. (1959). Dark carbon dioxide fixation by uredospores of rust fungi. Contributions from Boyce Thompson Institute 20, $71-82$.

Stover, R. H. \& FreiberG, S. R. (1958). Effect of carbon dioxide on multiplication of Fusarium in soil. Nature, London 18I, 788-789.

Tokunaga, J., Malca, I., Sims, J. J., Erwin, D. C. \& KeEn, N. T. (1969). Respiratory enzymes in the spores of Verticillium albo-atrum. Phytopathology 59, I829-I832.

VakiL, J. R., Rao, M. R. R. \& Bhattacharyna, P. K. (I96I). Effect of $\mathrm{CO}_{2}$ on the germination of conidiospores of Aspergillus niger. Achiv für Mikrobiologie 39, 53-57.

WANG, C. H. \& WiLlis, D. L. (1965). Radiotracer Methodology in Biological Science. Englewood Cliffs, New Jersey: Prentice-Hall.

WANG, M. C. \& BARTNICKI-GARCÍA, S. (1970).! Structure and composition of the yeast form of Verticillium albo-atrum. Journal of General Microbiology 64, 4I-54.

Wegener, W. S. \& Romano, A. H. (1964). Control of isocitratase formation in Rhizopus nigricans. Journal of Bacteriology 87, I56-161.

Wegener, W. S., Schell, J. E. \& Romano, A. H. (1967). Control of malate synthase formation in Rhizopus nigricans. Journal of Bacteriology 94, 195I-1956.

YANAGITA, T. (1963). Carbon dioxide fixation in germinating conidiospores of Aspergillus niger. Journal of General and Applied Microbiology 9, 343-35I. 